Informal Labour and Credit Markets: A Survey

Nicoletta Batini

Young-Bae Kim

Paul Levine

Emanuela Lotti

Working Paper No. 2011-94

November 2011

National Institute of Public Finance and Policy

New Delhi

http://www.nipfp.org.in 


\title{
Informal Labour and Credit Markets: A Survey
}

\author{
Nicoletta Batini \\ Young-Bae Kim \\ Paul Levine \\ Emanuela Lotti
}




\title{
Informal Labour and Credit Markets: A Survey*
}

\author{
Nicoletta Batini \\ IMF and University of Surrey \\ Young-Bae Kim Paul Levine Emanuela Lotti \\ University of Surrey
}

October 22, 2009

\begin{abstract}
This paper reviews the literature on the informal economy, focusing first on empirical findings and then on existing approaches to modelling informality within both partial and general equilibrium environments. We concentrate on labour and credit markets, since these tend to be most affected by informality. The phenomenon is particularly important in emerging and other developing economies, given their high degrees of informal labour and financial services and the implications these have for the effectiveness of macroeconomic policy. We emphasize the need for dynamic general equilibrium (DGE) and ultimately dynamic stochastic general equilibrium (DSGE) models for a full understanding of the costs, benefits and policy implications of informality. The survey shows that the literature on informality is quite patchy, and that there are several unexplored areas left for research.
\end{abstract}

JEL Classification: J65, E24, E26, E32

Keywords: Informal economy, labour market, search-matching models

\footnotetext{
${ }^{*}$ An earlier version of the paper was presented at an IMF APD Seminar, 22 April 2009. We acknowledge financial support for this research from the Foreign Commonwealth Office as a contribution to the project "Building Capacity and Consensus for Monetary and Financial Reform" led by the National Institute of Finance and Public Policy (NIPFP), New Delhi. We are indebted to Subrata Ghatak for helpful comments.
} 


\section{Contents}

1 Introduction 1

2 Literature on empirical evidence $\quad 3$

2.1 How do we measure the informal economy? . . . . . . . . . . . . . . . 3

2.2 The size of the informal economy . . . . . . . . . . . . . 5

2.3 Causes and impact of informality . . . . . . . . . . . . 7

2.4 Main stylized facts . . . . . . . . . . . . . . . 7

2.4 .1 Informal employment . . . . . . . . . . . . . . . . 7

2.4 .2 Informal credit markets . . . . . . . . . . . . . . . . 12

3 Informality in the labour market: early contributions 14

4 Informality and labour market frictions $\quad 15$

4.1 The intersectoral margin for workers and firms . . . . . . . . . . 16

4.2 The intersectoral margin for workers . . . . . . . . . . . . . . 17

4.3 The intrafirm margin and the occupational choice . . . . . . . . . 18

5 Informal credit markets $\quad 19$

5.1 Informal credit market, asymmetric information and formal-informal linkages 21

5.1 .1 Horizontal linkages . . . . . . . . . . . . . . . . . 21

5.1 .2 Vertical linkages . . . . . . . . . . . . . . . . 22

5.2 Informal credit markets and trading frictions . . . . . . . . . . . 23

5.3 Credit-constrained entrepreneurs, informal credit and labour markets linkages 24

5.4 Informal credit markets and monetary policy . . . . . . . . . . . 25

6 General Equilibrium models of informality 26

6.1 Informality in Computable General Equilibrium models . . . . . . . . . . . 27

6.2 Informality and Dynamic General Equilibrium models with wage flexibility 27

6.3 Endogenous growth and informality . . . . . . . . . . . 30

6.4 New Keynesian models with informal labour markets . . . . . . . . . . . . 31

$\begin{array}{lll}7 & \text { Conclusions } & 33\end{array}$ 


\section{Introduction}

Informality, usually regarded as an economic activity that is neither taxed nor monitored by the government, is common in emerging markets and developing countries where burdensome regulations and taxes coexist with poor public services and government's weak enforcement capabilities. From this perspective, informality is often the result of inefficient public policies and the presence of an informal sector ultimately reflects the failure of political institutions to protect and promote an efficient and equitable market economy.

That said, there is disagreement over the definition of informality; whilst we refer to it in a general way above, in fact it is a changing term with a focus on either the firm (ILO (1972)) or the worker (ILO (2002)). ${ }^{1}$ Furthermore, in some countries, i.e. India, the informal sector is identified with the unorganized sector whilst in advanced economies the term usually refers to the 'hidden' economy implying some kind of tax evasion. Finally, it is also evident that informality is a general term and it needs to be defined with respect to both product and factor markets. ${ }^{2}$

Is informality actually good or bad? The evidence is mixed. On the one hand, informality is often viewed as bad for a number of reasons: It leads to inferior working conditions, social vulnerabilities, low productivity, unfair competition, disrespect for the rule of law, erosion of the legitimacy and integrity of public institutions, corruption, and last but not least, low fiscal revenues. The latter in turn prevent improving public services and strengthening institutions in charge of tax and regulation enforcement, making it harder to get rid of informality in the first place. Importantly, as reviewed in section 6.2 , informality has been found to be negatively correlated with economic growth by compressing productivity and restricting access of informal firms and workers to necessary public services. The costs of informality appear even larger considering that the inability of enforcing environmental, workers' welfare and consumers' protection eventually hinders the integration of many developing countries into the global market in various ways.

On the other hand we report evidence revealing that informal credit markets are associated with positive growth rates (see section 6.2). In a world with imperfections in

\footnotetext{
${ }^{1}$ See Chen (2007) for a description of the move from the 'old' to the 'new' view of informality (Table 2 in this survey) as well as section 2.1 and Table 1 of this survey for the problems encountered in measuring informality given the lack of a unified definition.

${ }^{2}$ See Table 5.
} 
the product, credit and/or labour markets informality can increase efficiency and so can have a positive impact on the formal economy. This needs to be considered to arrive at a final conclusion on the overall impact of informality. For this reason, instead of focusing only on one aspect, a literature has emerged that assesses both the costs and benefits of informality. ${ }^{3}$

Recent accurate data on the size of the informal sector are available for a number of emerging market and developing economies as reported in section 2.2 of this survey. In some of these countries, for example in Bolivia, India, Nigeria, Panama, Pakistan, Paraguay, Peru, informality has been estimated to characterize over three quarters of the labour force and little less than a half of total sales-implying a shadow economy as large as 60 to 70 percent of GDP. (See Perry et al. (2007) for more details).

Recognition of the impact of informal behavior on economic activity has given impetus to a growing literature on informality over the past few years. This literature includes work that attempts to quantify the extent of informality in various countries and work seeking to explain the causes and the nature of the informal sector, either by establishing regularities in the data or by devising economic models for policy analysis that stylize informal behavior.

Given that a large informal economy is generally thought to be detrimental for the official economy, not surprisingly, research effort has been directed to analyze possible ways to reduce its size. Understanding what drives informal behavior and how the informal sector evolves and reacts to various combinations of public policies - including fiscal, financial, social protection, labour market and enforcement policies - is crucial for the design of measures conducive to significant reductions in present informality levels. Moreover, a knowledge of informal labour and credit markets is important to understand the monetary policy transmission mechanism and the conduct of an effective monetary policy.

This survey reviews this literature and can serve as a point of departure for future research in those areas that remain uncharted or that require a deeper understanding. Our survey goes beyond existing surveys on informality that limit their review to either labour markets (e.g. Fields (2005) and Perry et al. (2007)), regional evidence (e.g. Perry

\footnotetext{
${ }^{3}$ See Batini et al. (2009) reviewed in section 6.3.
} 
et al. (2007) that focuses exclusively on Latin America), or one type of equilibrium (like Ghosh et al. (1999) that focuses uniquely on partial equilibrium models of informal credit markets). ${ }^{4}$ By contrast we emphasize the need for dynamic general equilibrium (DGE) and ultimately dynamic stochastic general equilibrium (DSGE) models for a full understanding of the costs, benefits and policy implications of informality.

The rest of the paper is organized as follows. Section 2 surveys the empirical evidence on informality. Section 3 describes early models of informal labour markets. Section 4 introduces the three margins of informality and the standard search-matching model. First, it discusses the intersectoral margin for workers and the traditional concerns of wage dualism. Second, it analyzes theoretical developments on the intersectoral margin for firms and finally presents the most recent theoretical developments on the intrafirm margin and the occupational choice. Section 5 discusses informality in the credit sector. Section 6 describes the move to a dynamic general equilibrium approach to informality. Section 7 concludes with a summary of a number of open questions.

\section{Literature on empirical evidence}

The literature on the empirical evidence on informality takes at heart four main questions: 1) How do we measure the informal economy? 2) How large is the informal economy in the world? 3) What are the main drivers of the informal behavior? And last but not least, 4) What impact does informality have on the formal economy? Below we summarize key findings in these areas. ${ }^{5}$

\subsection{How do we measure the informal economy?}

How do we measure the informal economy? There are two approaches in the literature in attempting to respond this question. The first focuses on measures of hidden income, while the second on the size of informal employment. The size of the informal economy can differ considerably depending on which measurement we use.

Examples of the first approach include Schneider (2005) and Chaudari et al. (2006),

\footnotetext{
${ }^{4}$ See Table 1 for a description of the various aspects of informality.

${ }^{5}$ See Perry et al. (2007) for a detailed analysis on Latin American and Caribbean countries, Schneider and Enste (2000) and Schneider (2005) for a more global approach.
} 
who define informal all unregistered economic activities, which contributes to the officially calculated GNP. This strand of literature focuses on all the portion of income from legal activities not considered by the standard measurement procedures used for the compilation of national income accounts. A broader view includes illegal activities and the informal household economy, but a stricter definition looks mainly at all legal activities that would generally be taxable. Those activities are unreported mainly for tax evasion and to avoid social security contributions and other labour market regulations.

The National Commission for Enterprises in the Unorganized Sector (NCEUS from now on) reports on Definitional and Statistical Issues relating to the Informal Economy in India is an example of the second approach. According to this report, the informal (or unorganized) economy is given by the informal (or unorganized) sector and its workers plus the informal workers in the formal sector, where the unorganized (informal) sector is defined as all incorporated private enterprizes owned by individuals/households with less than 10 workers. Also the report defines unorganized (informal) workers, as workers in the unorganized sector, households, excluding regular workers with social security benefits, plus workers in the formal sector without any social security benefit (NCEUS (2008)) ${ }^{6}$.

From a methodological point of view, the size of the informal economy has been estimated directly and indirectly. The direct method relies on surveys or samples, while the latter uses macroeconomic indicators with information on informal activities. The main drawbacks of direct methods as survey or tax-auditing are that the information collected is often incomplete, samples can be biased, and also they refer to one point in time, lacking information on the development of the phenomenon over a period of time.

There are a variety of indirect methods to quantify the extent of informality. Schneider (2005) describes five of the most used methods. Schneider (2005), for example, opts for the currency demand and the DYMIMIC (dynamic-multiple indicators multiple-causes) methods. The former of these is based on the assumption that cash payments is used for hidden transactions so an increase in the demand of currency should reflect, separating all other possible causes, an increase in the number of hidden transactions. The latter of these, which is an evolution from the MIMIC or unobserved/latent variables approach is based on the critique that the shadow economy has an impact not only on money market, but also

\footnotetext{
${ }^{6}$ See ILO (2002) for a comparison of informal employment in various economies.
} 
on production and labour markets. The size of the hidden economy (unobserved variable) is influenced by a set of (measurable) indicators/causes such as the burden of taxes and regulation as well as tax morality, and change in labour force participation. Based on the statistical theory of unobserved variables, the unknown coefficients are simultaneously estimated in a set of structural equations typically by maximum likelyhood. The indicator variables are used to capture the effect of the unobserved variables indirectly. Different combinations of causes and indicators can then be used to provide different estimates (Chaudari et al. (2006)). This method provides a time-series index for latent variables, an ordinal index which is then converted into a cardinal series of values of size by scaling up ordinal values to cardinal values previously obtained through other indirect methods (i.e. currency-demand approach). One of the main criticism of this method is the lack of a theoretical link of causes and indicators with informality being the only unobserved variables linking them (Perry et al. $(2007)){ }^{7}$

In response to some of the criticisms of the MIMIC approach, Solomon (2008) uses a RBC model as a theoretical framework for choosing causes and indicators used in the estimation of the size of the informal economy.

\subsection{The size of the informal economy}

What is the size of the informal economy in the world? In general, data on the size, composition and contribution of informality is limited and international comparison of the scale of the phenomenon is difficult due to different measurement strategies. ${ }^{8}$ For this reason, the main findings are often supported by indirect measurement methods.

In general, as we saw above, estimates of the size of the informal economy can be in terms of income or in terms of employment. ${ }^{9}$ Chen (2007) reports that informal employment is about one-half to three-quarters of non-agricultural employment in developing

\footnotetext{
${ }^{7}$ See Appendix A in Schneider (2005) for a detailed analysis of the main methods used to estimate the shadow economy and to Dell'Anno (2003) for a detailed analysis of the MIMIC approach and its main criticisms.

${ }^{8}$ Many countries exclude agriculture and others include only an urban informal sector.

${ }^{9}$ We also would like to stress that direct methods depends on the definition of informality used. Henley et al. (2006) point out that the choice of the definition is often dictated by data availability. In their paper they compare different definitions of informality based on employment contract legislation, social security protection and employers/employees' characteristics using a complete household survey for Brazil.
} 


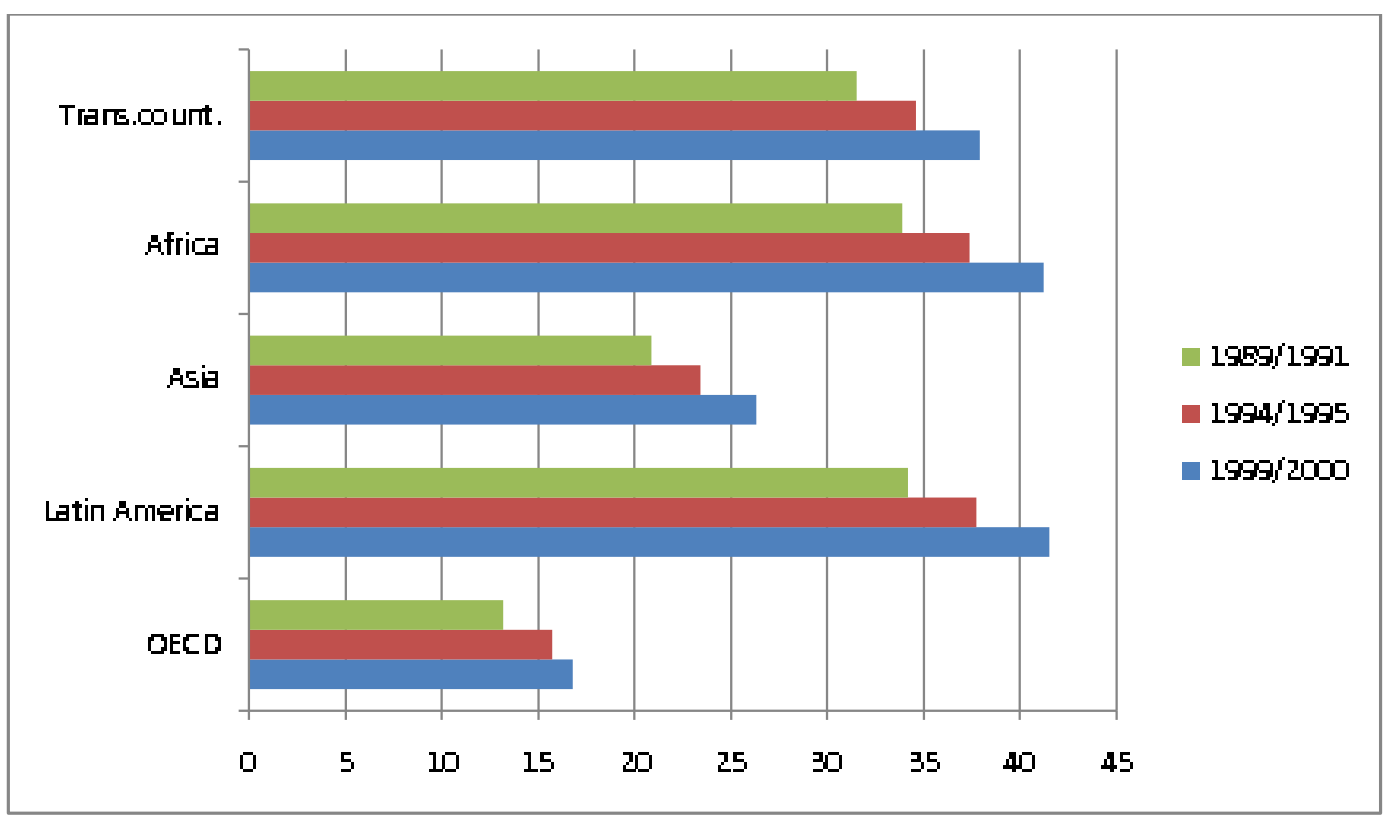

Figure 1: The Size of the Informal Economy around the World Schneider (2005)

countries. The estimate is likely to increase if we include the agricultural sector and other Asian countries in addition to India. Schneider (2005), using a combination of the DYMIMIC and currency-demand approach, reports results for 110 countries and reports data. The estimates show that the informal sector has increased considerably in African countries, but also in other developing economies. Upward trends are also found for transitional and developed economies. ${ }^{10}$

The increase in informality is partially confirmed in Perry et al. (2007) for a subset of countries. The general trend of informality for Latin American and the Caribbean suggests an increase over time even if differences exist between informal salaried and self-employed (Figure 1.9 of the report). See Table 3. A similar trend is confirmed in ILO (2002) ${ }^{11}$ Rei and Battacharya (2008) points out how data availability on informal employment is usually available for a limited set of countries, compared to the wider estimates of the informal economy provided in Schneider (2005). Also Box 1.3 in Perry et al. (2007) shows that when official statistics are available they may conflict with unofficial measurement of informality as in Schneider (2005).

\footnotetext{
${ }^{10}$ See Table 3.

${ }^{11}$ See Henley et al. (2006) for a discussion on the range of empirical definitions of informality employed in the literature
} 


\subsection{Causes and impact of informality}

What is the impact of informality on the formal economy? Loayza (1996) tests for Latin American countries in the 1990s predictions from his theoretical model: Countries with large tax burden and weak enforcement system should show a negative relationship between the size of the informal sector and economic growth. ${ }^{12}$ Results are confirmed with countries with very restrictive labour market regulations and poor enforcement systems showing the largest informal sector (i.e. Bolivia, Panama and Peru). Loayza (1996) also finds a negative relationship between the size of the informal sector and real GDP growth. In general, the relationship between informality and growth can be viewed in two of the following ways. Following Loayza (1996), the informal sector restrains growth because it reduces labour market productivity and hinders the enjoyment of public goods on the side of both workers and producers. An alternative hypothesis is that, in a world with various kind of imperfections (i.e. labour market regulation, corruption, etc.), the informal sector increases efficiency and so it has a positive impact on economic growth. Nikopour et al. (2008) reviews several papers investigating empirically the relationship between informality and growth for 21 OECD countries and concludes in favor of a positive impact of informality on growth.

Rei and Battacharya (2008) use regression analysis on low and middle-income countries' data to establish possible drivers of informality. Using Schneider (2005) data they find no general evidence on the impact of higher taxation and labour market regulation, but these results are not robust to the inclusion of indices of public and corporate governance. The main finding then is that strong or stronger governance favors formality.

\subsection{Main stylized facts}

\subsubsection{Informal employment}

Looking at the empirical literature discussed above, the following stylized facts emerge:

- developing countries tend to have a higher degree of informality than OECD countries (stylized fact 1, hereafter SF 1)

\footnotetext{
${ }^{12}$ The key assumption is that production technology depends on congestible public services and the informal sector has only a limited access to this services. See section 6.2 for a more detailed analysis of the theoretical model.
} 
- many countries reveal an increasing trend of informality (SF 2)

Those stylized facts on the size and trends across time seem to be confirmed by a specific studies in India by the (NCEUS). The official estimates, that identify the informal economy with the unorganized sector plus informal jobs in the organized sector, point to a growing trend of the already dominant unorganized sector in India. Also, another interesting stylized fact emerges:

- the informalization of the formal sector (SF 3)

With this definition, the Commission implies that there has been an increase in informal job (i.e. without job/social security) within the formal/organized sector. A similar trend is confirmed for Argentina and other Latin American countries in Perry et al. (2007) and Bosch and Maloney (2006). Bosch's modelling strategy described in section 4.3 explains these stylized facts (i.e the stipulation of informal contracts within a formal firm) through a stochastic job matching model.

An analysis of Mexican and Brazilian labour markets shows they have a relatively low unemployment rate compared to OECD countries. Bosch and Maloney $(2006,2007)$, looking at microeconometric evidence from gross worker flows in Brazil and Mexico claim that as a result of downturns and policy reforms, informal employment has changed considerably due to the following stylized facts:

- the job finding rate of formal jobs is highly procyclical (volatility puzzle), while the job finding rate of informal jobs is more stable (SF 4)

- the job separation rate in informal jobs is more responsive to negative shocks even though the separation rates for formal and informal jobs are both countercyclical (SF 5)

In general, Bosch and Maloney $(2006,2007)$ find that the hiring behavior of formal firms is the main driving force to affect the share of formal employment.

- During a recession, despite the large increase in the job separation rate for informal jobs, the share of formal jobs decreases (SF 6)

Also, and related to this, the evidence from Mexico and Brazil shows that flows from the informal to the formal sector are highly pro-cyclical while flows in the other direction 
are procyclical, but less volatile. As before, Bosch $(2006,2007)$ attempt to develop a theoretical framework to capture those stylized facts. Even though informality is mainly concentrated in the non-tradable sector, the author claims there is a need to model the change of the formal employment share within industries and occupation. This is in contrast with the idea that a change in the share of informality is due to sectorial changes as discussed in the NCEUS report whose findings point to an increasing trend towards more flexibility of employment, outsourcing and the growth of telecommunication and IT services as a possible explanation of the increasing share of informal employment in India.

Maloney $(1999,2004)$ provide evidence against the segmentation assumption. Maloney (1999) shows that despite a very large informal sector, labour markets are mobile and wages are flexible. Maloney (2004) shows that in many Latin American countries the informal sector is mostly voluntary. Finally, the evidence for Latin American countries shows that the informal labour market is ultimately heterogeneous and composed by, both self-employed and salaried workers.

Stylized facts on the cyclical behavior of informality are ambiguous. Normally, the informal sector expands during downturns (see previous stylized facts), but there is also evidence of pro-cyclical movements of the informal sector. Fiess et al. (2006) and Perry et al. (2007) provide a theoretical explanation in terms of asymmetric shocks between tradable and non-tradable sectors.

Empirical evidence on income and education between sectors point to the following stylized facts. Mastalioglu and Rigolini (2006) show that

- there is a negative correlation between the informal sector employment and education within countries as well as between informal employment and average education attainment across countries (SF 7)

Albrecht et al. (2008), described in section 4.2, provides an interesting framework to explain the facts above described. As the authors point out, their model is useful to explain the dynamics of the informal employment in many Latin American countries where it appears that the informal sector is an unregulated labour market in which low ability workers decide to work mainly with the status of self-employed. A similar view is adopted by Boeri and Garibaldi (2005) in section 4.1. Micro-level data for Italy show that shadow jobs are filled mainly by unskilled and lower educated workers (see SF 7). Cross-county 
and regional data for Brazil and Italy (i.e. two countries with a large informal economy) provide evidence of

- a positive correlation between unemployment and shadow employment (SF 8)

An attempt to explain the possibility that Governments hide high level of unemployment with the presence of a large informal sector is provided in the theoretical section of their paper.

Given that the search matching literature is mainly based on the idea that workers are free to choose between formal and informal sector, the empirical question related to the segmented or voluntary choice view of informality requires further investigation. Bosch and Maloney (2006) provide evidence that the performance of labour markets is asymmetric during business cycles. In particular, it supports the voluntary decision during expansion while it is in favor of segmentation during recessions. ${ }^{13}$ As pointed out in Perry et al. (2007), voluntary entry may not rule out some degree of market segmentation. While individuals are free to choose between the two sectors, the introduction of various labour market regulations make informal jobs less attractive or decrease the number of formal vacancies. In this sense, the search-matching literature reviewed in section 4 is able to take this sort of flexibility into account. See Satchi and Temple (2009) and Zenou (2008), reviewed in this survey, for a modelling strategy with search frictions focusing on the dualistic nature of informality.

Evidence on Latin America in favor of the existence of a wage premium for formal workers is ambiguous and depends on the category of informal job (i.e.self-employed are in general better paid than salaried workers). Different views are reported in the NCEUS report. In India the bulk of organized sector employment is paid employment (casual and regular/salaried), while the bulk of the unorganise sector is self-employment and poor quality casual workers. The report finds that while there seems to be no apparent different in wages for casual workers, regular workers in the informal sector are paid considerably less than their informal counterparts. Similar findings are reported in Badaoui et al. (2006) following an econometric studies using the South African Labor Force Survey. ${ }^{14}$

\footnotetext{
${ }^{13}$ See Perry et al. (2007) for further details on stylized facts concerning the voluntary or segmented view of informality.

${ }^{14}$ As noted in Perry et al. (2007), this traditional comparison of wages between sectors and the existence of a wage premium is not a proof of the existence of segmentation between formal and informal labour
} 
Further support of the segmented view can be found in Martin (2000) who shows that in Mexico

- the unemployment rate in the 1990's was low (3.7 per cent) and composed mainly by well-educated (SF 9). ${ }^{15}$

This evidence has been formalized by Satchi and Temple (2009) in a search matching model where workers who do not find a job are unlikely to have any other choice than to turn to the informal sector. ${ }^{16}$

Furthermore, Wahba and Zenou (2005) show that

- in Egypt, 70 per cent of workers obtain a formal job through formal methods (SF 10)

This fact is examined further in Zenou (2008) and in a general equilibrium framework by Batini et al. (2009).

Ihrig and Moe (2004) reviewed in section 6.1 attempt to explain the following stylized facts:

- a negative and convex relationship between informal employment and country's standard of living (SF 11)

- a positive relationship between informal employment and tax rate (SF 12)

Refer to Figures 1 and 2 in Ihrig and Moe (2004).

Finally, as far as the link between informality and (gender) inequality is concerned, various studies, including Chen (2007) report that informal employment is an important source of employment for women than for men in LDCs and globally the following stylized facts emerge:

- a significant gap in earnings within the informal economy with employers at the top segment followed by their employees (regular salaried) and by casual workers (SF 13)

markets.

${ }^{15}$ In general, many studies show that unemployment rates in developing countries are low compared to OECD countries. See for instance Bosch and Maloney (2006) and Bosch and Maloney (2007).

${ }^{16}$ See section 4.2 . 
- men are over-represented in the top segment while women are over-represented in the bottom segment and the share of women/men in the intermediate segments varies across sectors and countries $(\mathrm{SF} 14)^{17}$

From those facts emerge an informal sector which is mainly voluntary for employees while salaried and casual workers are often left with no other choice than to accept the job available for them given their skills and constraints (i.e. women and requirement of flexibility). We think, more theoretical work is required to address stylized facts 13 and 14 .

\subsubsection{Informal credit markets}

Informality in credit markets is strong in many developing countries like India, Pakistan, Indonesia, Brazil and many African countries, but also in emerging market countries like China. Unfortunately, data on the size of informal credit markets is scant. According to Bell (1990), over 80 percent of all Indian rural households' debt was borrowed from the informal credit agencies (excluding relatives and friends which cover about 11 percent) in 1951 but it was a mere 24 percent in 1981. At the same time, the proportion of debt owed to the formal credit institutions has risen dramatically overtime from 61 percent in 1981 to 7 percent in 1951 and thus the share of informal credit markets is about 39 percent. This follows the creation of the rural cooperatives in the 1950s that is believed to have displaced the informal moneylenders in India. However, such figures for the informal credit market have not changed very much in the 1980s. Data from the All-India Debt and Investment Survey (AIDIS, 2003) shows that for the Indian economy the share of moneylenders is over 9 percent while the share of non-institutional to total is over 36 percent.

From the above trends, an additional set of stylized facts (SF) emerges:

- economies with less developed credit markets tend to have more segmented credit markets, and thus, greater informal credit markets (SF 15)

In conjunction with the previous stylized fact, Barth et al. (2004) and Beck et al. (2004) observe that:

- both formal and informal lenders in less developed credit markets have extensive market power (SF 16)

\footnotetext{
${ }^{17}$ See Figure 1 in Chen (2007) for details.
} 
However, the creation of the rural cooperatives in India does not enhance the volume of funds available in credit markets but also increases competition in the formal credit markets, inducing another stylized fact:

- informal credit is more important the more concentrated are formal credit markets (SF 17)

Further relevant evidence for China can be found in Cull and Xu (2005), Chen and Degryse (2008) and Ayyagari et al. (2008).

There are some some mixed trends in the distribution of credit when both formal and informal credit markets are present:

- the distribution of formal loans to rural households favors wealthy borrowers or large farms while the majority of informal loans were distributed to poor borrowers or small farms (SF 18)

Relevant evidence can be found in Siamwalla et al. (1990) for Thailand and Kochar (1997) and Banerjee and Duflo (2007) for India;

- a high proportion of all borrowers obtain credit from both formal and informal credit markets simultaneously (SF 19).

See Das-Gupta et al. (1989) for India, Conning (2001) for Chile and Gine (2007) for Thailand; and

- informal moneylenders obtain formal credit to fund their informal credit services (SF 20)

See Hoff and Stiglitz (1990), Ghate et al. (1992), Irfan et al. (1999) and Madestam (2009).

Credit may be rationed in some periods and credit markets are segmented with local moneylenders, borrowers with no collateral may have to seek informal credit with high interest rates. Interest rates charged by moneylenders in informal credit markets may exceed 75\% per year (Besley (1994) and Hoff and Stiglitz (1990)).

- informal interest rates are on average much higher than formal rates (SF 21)

Furthermore, Banerjee (2003) shows that 
- interest rates charged by informal moneylenders may range from 0 to 200 per cent per year in India, Pakistan, and Thailand (SF 22)

The theoretical rationale for multiple informal interest rates will be reviewed in section 5 .

\section{Informality in the labour market: early contributions}

There are different ways of modelling the informal sector adopting a non-Marshallian view of labour markets. ${ }^{18}$ Starting from the classical Harris-Todaro framework, early modelling in this area has been very prolific.

The basic analytical set up used by this literature is similar to that used in the literature on migration (Todaro (1969) and Harris and Todaro (1970)) and the modelling approach adopted by the migration with search literature. As pointed out by Zenou (2008), the earlier analytical framework - where only one side (i.e the worker) is modeled (Fields (1975)) - differs from later set ups that have incorporated the Mortensen-Pissarides model in a migration equilibrium (Ortega (2000) and Sato (2004)).

The early studies by Todaro (1969) and Harris and Todaro (1970) capture informality by building a model of two geographically distinct markets that are segmented and in which two different wage equilibria prevail (wage duality), where wages in the formal sector can turn out to be higher-than-market-clearing wages. ${ }^{19}$ Brueckner and Zenou (1999b) add a land market to the standard Harris-Todaro framework where wages are exogenously fixed. The idea of identifying the informal labour market with the disadvantaged sector of a market segmented by rigidities in the formal sector dates back to Lewis (1954) and the idea of infinite labour supply. ${ }^{20}$

More recent work, like Brueckner and Zenou (1999a), take a different approach and introduces efficiency wages. Developments in the theory of imperfect information allows to introduce labour dualism as a result of a firm's response to adverse selection and moral hazard problems. In general, there are many models that can be used to justify duality and the presence of a higher wage in the formal sector, but this always requires an ad

\footnotetext{
${ }^{18} \mathrm{~A}$ view where labour market does not clear.

${ }^{19}$ See Lall et al. (2006) for a survey on rural-urban migration.

${ }^{20}$ Similarly, the report of the International Labor Office (ILO (1972)) on employment in Kenya considered the informal sector as a subsistence sector.
} 
hoc assumption about some features characterizing the formal rather than the informal sector. $^{21}$

Yet another initial way to model informality involves cost-benefit analysis. Within this approach, the informal sector is seen as an unregulated, largely voluntary, sector (Lucas (1978) and Rauch (1991)), where agents ponder the costs of becoming formal against the benefits of being informal.

In section 4 we will review recent advances in modelling informality in the presence of labour frictions, namely the search-matching theoretical framework and its multi-sectoral extensions. Relative to the models of the Harris-Todaro tradition, the richer labour market structure of the search-matching framework determines the wage in the formal sector endogenously, and allows for a wider range of effects to be analyzed. Relative to the voluntary view of informality, the search-matching approach microfounds the decision of firms and workers to enter the formal/informal sector, while distinguishing among the three margins of informality by focusing on the flows between formal and informal labour market, and unemployment.

\section{Informality and labour market frictions}

Building on the earlier literature, a variety of more sophisticated models have been developed to portray formal, informal and integrated labour markets. In these models, trading frictions in the formal and/or informal sectors are important and it is possible to determine rules governing the flows between the two sectors, as well to and from the pool of unemployed.

For most of these second generation models, the workhorse model involves incorporating the search matching model of Mortensen-Pissarides in Harris and Todaro (1970)'s model. In this case the question of how informal-formal jobs are created is not very different from the distinction between the creation/destruction of rural and urban jobs and the approach is in line with the standard equilibrium model of the labour market with market frictions and occupational/participation choice (e.g. McKenna (1987) and Garibaldi and Wasmer (2001)).

\footnotetext{
${ }^{21}$ The "old search" literature with migration (Fields (1975)) can also be considered an early attempt to explain and model the existence of an informal sector.
} 
Other models emphasize the voluntary aspects of informal behavior by by focusing on the worker's decision to be in the formal or in the informal sector Albrecht et al. (2008). Similarly, a number of papers focus on the firm's decision to open a formal or an informal vacancy. Finally, Boeri and Garibaldi (2005) and Frankel and Pissarides (2006) endogenize, both workers' and firms' decision to join either the formal or informal sector. Table 4 summarizes the main characteristics of this literature. Below we review in more detail the three types of models that dominate the search matching-model-based literature on informal labour markets.

\subsection{The intersectoral margin for workers and firms}

Boeri and Garibaldi (2005) solve a deterministic search-matching model with heterogeneous workers and find that workers with different skill sort themselves between the two sectors. The intuition is the following: because informal employment (shadow employment in the paper) is associated with more labour turnover, it discourages high-skill workers. The driving assumption is that unemployment benefits are small enough, but a similar sorting can apply to a framework where the informal economy is characterized by lower capital intensity and no training commitment. The authors choose a framework with two labour markets with frictions and two matching functions. The marginal worker than is indifferent between being unemployed in the formal or in the informal sector. Also Fugazza and Jacques (2003) assume that there are important search frictions in both the formal and the informal sector since working informally requires "special connections and the access to the network is time consuming". The model solves for two arbitrage condition, one for the firms and one for the workers. More than one equilibrium can arise depending on a parameter which summarizes the relative profitability of the regular and the irregular sectors. The analytical and numerical exercises of the paper reveal interesting policy analysis which will be discussed in the following sections. Badaoui et al. (2006) adopt a Burdett and Mortensen search framework (Burdett and Mortensen (1998)) in which large firms pay a higher wage than small firms and concentrate in the formal sector. Small firms, instead, tend to choose the informal sector. The key factor in the informality choice is that small firms are less likely to receive a tax inspection respect to large firms. In presence of search frictions, a wage premium in the formal sector arise since large firms 
are more likely to pay a higher wage. The duality between formal and informal sector is explained by firm size without the need of introducing any sort of heterogeneity among workers.

\subsection{The intersectoral margin for workers}

A sorting similar to Boeri and Garibaldi (2005) is described in Albrecht et al. (2008). The paper analyzes worker's decision to enter the formal or the informal sector using a searchmatching model with endogenous job destruction. Workers have the same productivity in the informal sector (self-employment) while they have different productivity if they decide to enter the formal sector. In this way the relative productivity in the two sectors is an important factors in the workers' choice. Workers with high productivity levels accept only formal job offers. There are only formal sector firms and they do not know in advance what type of worker they will meet. In this framework, workers trade-off their abilities in the formal sector with a higher job creation in the informal sector.

Also Zenou (2008) assumes that homogeneous workers in the formal sector are more productive than workers working informally. This difference in productivity is justified in terms of better technology, access to infrastructure etc. The paper shows that the informality is a result of market frictions in the formal sector. ${ }^{22}$ As Albrecht et al. (2008), Zenou (2008) distinguishes between three labour markets: the formal sector, the informal sector and 'formal' unemployment. In Zenou's the informal sector is competitive and the marginal worker trade-off the higher productivity of the formal sector with the friction-less competitive market where all workers find a job. This framework largely simplifies the analysis and allows for analytical solution and interesting policy analysis. It also implies that worker's decision to work formally or informally is based on an endogenous outside option. ${ }^{23}$

Are there more coordination failures in the formal firms than in the informal one or does the informal sector need special connections which are more time consuming? Zenou assumes at the limit that there are no frictions at all in the informal sector and this is justified by the fact that informal workers are mainly self-employed or they work for

\footnotetext{
${ }^{22}$ The author notes that without market frictions all workers would enter and find work in the formal sector.

${ }^{23}$ The marginal productivity of informal labour decreases when the labour supply in that sector increases.
} 
relatives and friends while formal jobs require formal application processes (see SF 10). Within the informal network, world-of-mouth communication is important and there is no need of a formal search process. This is in contrast with Fugazza and Jacques (2003). Satchi and Temple (2009) introduces a search-matching framework in a model of the Harris and Todaro (1970) tradition. The authors allow for an urban sector with formal and informal jobs and an agricultural competitive sector. As in Zenou (2008), this allows for an endogenous outside option for workers which trade-off the higher productivity of the urban sector with the security of a job in the agricultural sector. The main downside of their theoretical framework is that it does not distinguishes unemployed from informal workers and the informal sectors is seen as "marginal forms of self-employment, made possible by low entry costs". Workers that cannot find a job formally because of searchfrictions simply turn to the informal sector. The authors introduces endogenous capital in the formal sector of a small open economy and recognizes the importance of a general equilibrium analysis. Finally, Kolm and Larsen (2003) model worker's choice to enter the formal sector in a search-matching model where agents with different abilities have the option to acquire education. This theoretical analysis allows for the interactions and the endogenous determination of unemployment, informality and educational levels.

\subsection{The intrafirm margin and the occupational choice}

Bosch (2006) explains the rationale for the existence of both formal and informal contracts within the same firm by modelling the within firm decision of employing informal labour. Bosch (2007) generalizes the intra firm margin of informality of Bosch (2006) in a framework with occupational choice. In particular, the author assumes that heterogeneous individuals sort themselves between workers, informal self-employed and formal entrepreneurs. The latter are then able to exploit the intra-firm margins of informality by employing, both, formal and informal labour. An increase in labour market regulations can expand informality through the intra-firm contract decision and also by expanding the informal self-employment. Bosch (2006 and 2007) models the intrafirm margin by extending the basic search-matching model and allowing for ex-post match heterogeneity.

Formally, the choice of a stochastic job matching framework allows for optimal hiring decision of the firm in function of the productivity of the match between firms and ex- 
ante homogeneous workers. Only matches with high productivity will result in formal contracts.

\section{Informal credit markets}

In this section we review the different ways in which the literature has dealt with modelling informality in credit markets instead of labour markets, in a partial equilibrium context. Models with a frictionless labour market mainly analyze informality in terms of other kind of imperfections. The participation to the informal economy usually implies a cost in terms of limited access to a public good or to formal credit markets. A large informal credit market also could have an impact on the efficacy of monetary policy, but so far theoretical work is very limited (or missing) in this area.

As reviewed in section 2, informal moneylenders on average charge much higher interest rates than formal interest rates due to segmented credit markets while informal interest rates range from 0 to 200 percent par year. Relatively low interest rates in informal credit markets (say, less than 75 per cent per year that would be on average) can be justified by friends and family lending or multiple lending from both formal and informal financial markets (Madestam (2009)). As explained in Hoff and Stiglitz (1990), (rural) informal credit markets do not work neither as classical competitive markets, nor as markets where the local moneylender has a monopoly power. The explanation of the higher interest rate charged has normally been attributed to a lack of information. Adverse selection, moral hazard and also imperfect enforcement require costly mechanisms such as the design of contracts, screening process, etc. Also banks rely heavily on collateral and, by definition, informal firms lacking of collateral, are left with one only option: borrow in the informal credit sector. This is the case of Thailand, India and the majority of developing countries.

Ghosh et al. (1999) refers to three strands of the literature in the area of informal credit markets: adverse selection, moral hazard and imperfect contract enforcement. Indeed, informal credit markets have often been associated with the existence of imperfect information in financial markets and limited enforceability. Imperfect information can generate adverse selection, moral hazard and search externalities.

Below we look at key papers in each strand of the literature and identify some characteristic modelling strategies. A common feature is that, due to a general lack of collateral, 
entrepreneurs in the developing world are credit-constrained and a significant fraction of credit is still in the hands of operators in the informal credit market despite the development of a formal credit system. Ghosh et al. (1999) review the different modelling strategies in the partial equilibrium analysis of informal credit markets. The authors point to informal credit markets and moral hazard and limited enforceability by distinguishing: models with involuntary and with voluntary default. The main result highlighted in the survey is that despite the different modelling details, the models share a common view: credit rationing appears as a rational response to information and enforceability problems and the small firms with minimum or none collateral seem the more exposed. As far as policy recommendations are concerned, the authors call for measures aimed at improving the institutional environment such as improving borrowers' bargaining power,decrease in asset inequality etc. instead of macroeconomic policy aimed at increasing the interest rate. Yunus and Weber (2007) contribute to the debate on the impact of microcredit on the standard of life of the very poor. The author adopts a revolutionary approach and look at the positive impact of informal credit on the development and standard of life in the developing world. Microcredit, following Yunus's definition targets the very poor, particularly women, and it is based on trust since the lack of collateral is one of the main limitations of borrowing from standard financial institutions.

As far as theoretical work on credit-constrained entrepreneurs and informal credit market is concerned, firstly, we look into papers that focus on adverse selection and moral hazard. The literature in this area clearly assumes missing markets to explain the emergence of an informal credit market. Secondly, we investigate theoretical modelling with credit constraints due to search externalities. This strand of literature only mention, without explicitly models, informal credit markets. Thirdly, we review papers that model the decision to be formal or informal by assuming the lack of access to formal finance as one of the main cost of going informal. Finally, we move onto papers that investigate the relationship between informal credit markets and monetary policy. 


\subsection{Informal credit market, asymmetric information and formal-informal linkages}

The literature on informal credit markets explains informality in the financial sector as a cause of pre and/or post-contractual imperfect information which generates problems of adverse selection and moral hazard. According to this literature, credit-constrained individuals with limited access to formal banks try to borrow money informally.

\subsubsection{Horizontal linkages}

Within this framework, formal banks compete directly with informal moneylenders. Individuals can access credit in a two tier process by first approaching formal banks with excess liquidity, and then, as this is no longer available, move onto informal moneylenders to borrow residual funds. Bell (1990) examines the impact on the rural credit market in India of the introduction of a system of rural cooperatives in the 1950s. Indian data shows that the creation of the rural cooperatives displaces the informal moneylenders. In an analytical framework, Bell (1990) shows that such a trend arises because the monopolistic market power of the rural moneylenders is curbed by the increased competition from the formal credit institutions such as cooperatives, banks, and government.

Kochar (1997) investigates credit rationing constraints in rural credit markets in India and particularly, separates the demand for credit from the lenders's decision on access. Kochar recognizes the fact that the provision of formal credit to rural farmers at a relatively low interest rate in an attempt to expand agricultural investment may lead to an excess demand for formal credit, and thus tougher formal credit rationing constraints. It is such rationing constraints that impart a dual nature to the rural credit market: the formal regulated sector and the informal sector. Both Bell (1990) and Kochar (1997) argue that the rationing constraints such that lenders have to charge a high rate for risky households due to the high screening and monitoring costs would limit the role of formal credit in enhancing rural investment and reduces the demand for credit.

Arnott and Stiglitz (1991) investigate the theoretical underpinnings of insurance markets characterized by moral hazard, and show how moral hazard can have a mixed impact of non-market insurance institutions. Households and firms borrow from friends, family and neighbors when hit by an adverse shock, and pay back later when things get better, as 
reported by Aryeetey et al. (1997). Such informal mutual assistance between non-market institutions is unobservable to market insurers and its impact appears to be either negative or positive, depending on the market structure. From their model, it is predicted that, when formal and informal insurers have the same information, the informal insurance crowds out formal insurance leading to welfare-inferior outcomes. In contrast, when informal insurers have a better position in peer monitoring, the existence of informal insurance is welfare-enhancing. (See, among others, Stiglitz (1990) and Banerjee et al. (1994).)

\subsubsection{Vertical linkages}

Informal lenders have access to formal banks and so can use funds generated formally for lending in informal markets. Hoff and Stiglitz (1997), Floro and Ray (1997), Bose (1998) and Madestam (2009), among others, discuss this vertical interaction between formal and informal credit sectors. Most of these studies report the adverse effect of government policies of providing low-cost or subsidized credit to the agricultural sector through the formal credit institutions such as cooperatives and banks. Hoff and Stiglitz (1997) develop models to show that with endogenous enforcement costs, government-subsidized formal credit may not be not able to enhance agricultural investment. Subsidies may attract more moneylenders to enter the informal credit market leading to higher interest rates through three channels. A rise in new entry may raise the marginal transaction costs (via economies of scale), increase the marginal enforcement cost of moneylenders due to reduced borrowers'incentives to repay (via enforcement externalities), and reduce the flows of information about each borrowers' credit history and thus weaken "reputation effects" that punish defaulters. Through these three effects, subsidized funds may eventually raise interest rates and reduce the availability of loans in the informal sector. Bose (1998) argues that although the informal moneylenders as a whole have some relative advantage in collecting, screening, and monitoring the information about borrowers' credit history and investment behavior, they may also face the problem with the asymmetric information about the borrower-specific degree of risk. Such heterogeneity in moneylenders and borrowers brings about adverse composition effects and, in turn, increase interest rates charged by moneylenders as in Kochar (1997). Floro and Ray (1997) reach a similar conclusion but with different reasoning. Considering the special case of Philippines, they find that an 
expansion of credit available to informal lenders through the formal sector might trigger aggressive lending (like a credit war). In a repeated game framework, moneylenders might then decide to collude among themselves leading to higher interest rates.

The findings in Madestam (2009) are in line with the above studies using a model that like those assumes formal and informal credit sectors, but that in addition assumes that informal moneylenders are heterogeneous. Two types of lenders exist in the informal credit market: rich informal lenders who do not to borrow formally to lend informally, and poorer informal lenders who must access banks to fund their business. The model rationalizes the coexistence of formal and informal credit markets assuming that formal and informal lenders face different agency and monitoring constraints (for example, informal lenders are able to closely monitor borrowers who are usually known clients whilst banks have limited information on moral hazard at the investment stage). The main findings of the paper is that the existence of informal finance results in three effects. First, informal credit leads to the "investment effect" such that additional informal finance increases the investment of bank rationed borrowers by channeling bank funds to informal lending. Second, informal credit generates a "disciplinary effect". Since borrowers in informal markets do not need to pay agency costs that usually arise from bank finance, the borrowers' return to investment is higher than otherwise and they have less incentives to default, leading to increased bank lending. Finally, the agency problem leads to the "rent-extraction effect". By letting informal lenders with good credit or collateral channel bank funds to informal borrowers, banks are able to avoid high agency costs arising from directly lending to poor borrowers (in addition to the monitoring problem), preventing borrowers from accessing bank finance. As a result, if the rent-extraction effect prevails, borrowers are worse off. Using this model, Madestam (2009) also investigates the role of market power in the banking sector, reaffirming the general finding that the stronger this is the less efficient the credit market equilibrium. When the banking sector has higher market power, the rent-extraction effect dominates, and as a corollary informal credit markets are more prevalent .

\subsection{Informal credit markets and trading frictions}

As discussed, one way to model credit rationing is by introducing imperfect information. While models with moral hazard and adverse selection in financial markets have been 
widely discussed in other surveys ${ }^{24}$, the role of search externalities in credit markets has only recently been recognized. Within this framework, market liquidity depends on the matching process between borrowers and lenders. This literature suggests that search frictions in credit markets are particularly useful in the modelling of informal labour an product markets where informal firms cannot rely on collateral and need to contact informal moneylenders. Wasmer and Weil (2004) develop a model with credit and labour market imperfections due to trading frictions in both markets ${ }^{25}$ where labour and capital imperfections are symmetric. Assumptions in this model depart from the traditional search and matching literature because here entrepreneurs need to finance the search process and need to find a lender (i.e. a moneylender in the informal credit market) to start-up a business activity. Likewise, Becsi et al. (2005) model credit market activity within a search match framework where borrowers are heterogenous. A few other papers adopt trading frictions in the credit markets (Dell'Ariccia and Garibaldi (2000) among the others), but to the best of our knowledge, none has explicitly used trading frictions in the credit market to model the firm's decision to enter or not the informal sector and trading frictions in the credit market have not yet been incorporated in a DSGE model. Wasmer and Weil (2004), by introducing financial imperfections, provide a simple measure of the financial accelerator based on the idea of a 'credit gap': credit market frictions reduce the number of entrepreneurs discouraged by the lower probability of finding a lender, and in turn this creates a negative externality by reducing the number of lenders, accelarating the adverse implications of a contraction in credit. This way credit market imperfections magnify the negative consequences of economic shocks. The authors show that the excess return on business loans, i.e. the "credit gap", depends on the bank's bargaining power and on the degree of market imperfections.

\subsection{Credit-constrained entrepreneurs, informal credit and labour mar- kets linkages}

In the firm's choice between operating formally or informally (i.e. intrafirm margin), access to informal credit markets is often represented as one of the costs of going informal.

This is the approach taken by Straub (2005) where access to formal credit markets and

\footnotetext{
${ }^{24}$ See Ghosh et al. (1999).

${ }^{25}$ The model assumes risk-neutral agents and take the interest/discount rate as given.
} 
key public goods (property rights and contract enforceability) interact with the entry costs in the formal sector. The model is based on two of the above mentioned costs due to the lack of information: creation of the right incentives and "Mafia-style" enforcement. The author builds on the investment model with moral hazard by Holmstrom-Tirole (1997)to show that the choice between formal and informal sectors depends on the registering costs, the relative efficiency of credit markets, initial wealth and collateral.

Along these lines, de Paula and Scheinkman (2007) explore what are the implications of having (or not) access to formal credit markets. The authors model informality in an occupational choice model where low ability agents work as salaried workers or become managers in the informal sector while high ability individuals prefer to be managers in the formal sector. The definition of informality is in terms of tax avoidance (evasion dualism). In equilibrium, the marginal firm is indifferent between the obligation of paying taxes on the one hand and the higher cost of capital together with scale limitations on the other. In particular, informal firms face a higher cost of capital and a probability equal to one to be detected if their capital is above a threshold value. Capital here is a proxy for the size of the firm. Other authors before show that the size of the firm is an important factor in the distinction between formal and informal firms, Rauch (1991) de Paula and Scheinkman (2007) add capital and show that constrained and unconstrained informal firms have a lower capital-labour ratio than formal firms. They then develop a model with two production stages and show that the informality of a firm is correlated to the informality of its upstream and downstream sector. Also based on Rauch (1991), Antunes and Cavalcanti (2007) model the firm's decision to be formal or informal. In particular, risk-neutral agents decide to be workers or entrepreneurs in function of their talents. Entrepreneurs then decide to be formal or informal through a cost-benefit analysis in which they weight the possibility to avoid taxes and regulation costs with the imperfect access to formal credit markets.

\subsection{Informal credit markets and monetary policy}

The implications for monetary policy of informal behavior in credit markets are controversial. One set of scholars examining this in the context o low income countries, for example, argues that low interest rate policy would reduce the cost of physical capital and 
thus promote capital accumulation and growth when credit markets are segmented and lower income households are credit constrained and thus, can only access informal credit markets. The monetary and fiscal policy implications for keeping rural interest rates low is illustrated in Ghatak (2007): Once farmers have higher real income, they will raise their repayments, reducing the risk premium and thus the interest rate. Measures to raise real income suggested include low inflation as well as increasing agricultural output through rural innovation. In this scenario, inflation not only reduces farmers' real income but also moneylenders' real value of repayments, inducing higher interest rates which, in turn, compensates for non-performing loans.

On the other hand, McKinnon (1973) and Shaw (1973) emphasize the importance that funds remain market-determined and are not rationed as a consequence of interest rate interventions (e.g. administratively-enforced caps) because this promotes the accumulation of money balances which, in their view, are complements and not substitutes of physical capital. Financial regulation restraining real interest rates as well as other forms of selective credit control could reduce savings and investment while perversely enhancing segmentation of financial markets. Therefore, these scholars argue that policies of financial liberalization that free real interest rates in formal credit markets can increase savings and capital accumulation (see e.g. Fry (1978)) with benefits for borrowers of all income levels. One criticisms of this view can be found in Taylor (1983) and van Wijnbergen (1982), who maintain that if interest payments account for a large proportion of total production costs, aggressive financial liberalization ending up in strong increases in borrowing costs by low income producers could well lower overall output, and divert credit away from informal markets into formal banking sectors, thereby raising further informal interest rates, and reducing informal borrowing and investment by lower income agents (Thornton and Poudyal (1990) and Ghatak and Chandio (2009)).

\section{General Equilibrium models of informality}

Although many recognize the importance of modelling informal behavior within general equilibrium set ups (e.g.Satchi and Temple (2009), Marjit and Kar (2008) Sinha (2005) and Zenou (2008)) most general equilibrium search matching models either incorporate ad hoc representations of informality or assume it away altogether. For example, stan- 
dard assumptions in the search-matching literature (i.e. linear utility function among the other), exclude the consumption-hours decision which is at the heart of more comprehensive models of informal behavior. In this section we summarize the literature advances in the general equilibrium environment with informality. First, we look at the way Computable General Equilibrium (CGE) models include an informal sector. Second, we look at simple dynamic general equilibrium models with wage (and price) flexibility. Third, we look at the literature that studies the long-term impact of informality adopting an endogenous growth framework. Finally, we review the analysis of informality embedded in New Keynesian set ups with price and wage rigidities.

\subsection{Informality in Computable General Equilibrium models}

Sinha (2005) Sinha and Adam (2000), Gibson and Kelley (1994) and Portes et al. (1989) analyse the informal sector in a macroeconomic framework using a computable general equilibrium (CGE) structure. CGE modelling, also referred as AGE (Applied General Equilibrium) models, use actual data to estimate the impact of mainly technological and policy changes within a database consisting of input-output table, elasticities, etc. This kind of modelling strategies were often used for developing countries where time series data were scarce. Compared with the more recent general equilibrium modelling strategies, the CGE models are mainly static (i.e. they model the reactions of the economy at one point in time). Sinha (2005) provides a 'mini' survey on CGE models including an informal sector and differentiates CGE models focusing on informality in product markets Gibson and Kelley (1994) and CGE models based on segmented labour market theories (e.g.,Portes et al. (1989)) where informality is defined in respect to the factor markets.

\subsection{Informality and Dynamic General Equilibrium models with wage flexibility}

Agenor and Montiel (1996) introduces a series of simple macroeconomic models which are then used in Marjit and Kar (2008) for various policy experiments with an informal labour market. The authors model capital mobility between formal and informal sectors with the purpose to analyze the impact of deregulation on informal wages. The intuition is the following: in developing countries people cannot afford to be unemployed so if they 
do not find a job they work in the informal sector (i.e. unemployed as informal workers as in Saatchi and Temple). ${ }^{26}$ "It may be argued that the problem of the very poor and the unskilled was never lack of jobs, but the wage rate". According to this, it is the wage rate and not the employment status a criterion to measure the standard of living in the developing world (Marjit and Kar (2008)). Ihrig and Moe (2004) develop a dynamic general equilibrium model with 2 sectors: a formal sector where firms employ labour and capital and an informal sector with firms employing only labour (i.e. there is a fixed stock of capital). The economic agents decide between consumption and savings and the time allocated to the two sectors. As capital increases in the formal sector labour moves from the informal to the formal sector until the marginal productivities of labour in the two sectors are equalized. The main trade-off is between paying taxes to the government or access to formal capital markets.

Conesa et al. (2002) present a similar model, but introduce a stochastic element. To the best of our knowledge, this is the first DSGE model that incorporates an informal sector. The authors introduce a second sector into a standard Real Business Cycle (RBC) model which is described as an "underground" economy that has a different technology, produces goods and services that could otherwise be produced in the formal sector, but is not registered in NI accounts. As pointed out by the authors, ... "The tradability of the output generated by this activities is the key features distinguishing our approach from the household production literature. The main characteristics of the model include: a wage premium which can be seen as the opportunity cost of not working in the official sector and labour indivisibilities in the formal/registered sector. Households choose a probability of working in the informal sector which can be interpreted as the purchase of lotteries in a perfectly insured market. When a worker chooses the informal sector he/she enjoy more leisure at the price of a smaller wage, while in the formal sector individuals work more, but receive a wage premium. In particular, the authors assume labour to be indivisible in the formal/registered sector with hours worked fixed exogenously.

The main prediction of the model is that wage premium differentials can explain the different size of macroeconomic fluctuations as a function of technological shocks. The intuition is the following: countries with a smaller wage premium have a lower opportunity

\footnotetext{
${ }^{26}$ Satchi and Temple (2009) develop this idea in a search-matching model and for this reason the paper is discussed in section 4 .
} 
cost to participate in the formal sector and so they have smaller participation rates. In those countries, the effects of technological shocks are amplified.

Cavalcanti and Villamil (2003) in a dynamic model with a household sector show how the Friedman rule of zero inflation is not optimal in countries with a large informal sector (labour, good or financial markets). In their model, individuals allocate time between consumption and labour in the formal or informal sector. The main idea is that if government's ability to tax in the labour and commodity markets is limited, an inflation tax decreases those distorsions. The efficacy of monetary policy in a framework where part of the economy is not observable (i.e the informal sector) is analyzed within a DSGE framework in Batini et al. (2009) and will be discussed in section 6.3.

In section 2 we show evidence in support of the idea that self-employed and informal workers are mainly concentrated in non tradables (Brazil 92\%, Colombia $87 \%$ and Mexico 83\%). Fiess et al. (2006) and Loyaza and Rigolini (2006) develop two macroeconomic models to investigate the nature of the informal sector. The former looks at the behavior of the informal sector during a business cycle as a reaction to temporary and permanent macroeconomic shocks. The latter studies the evolution of the steady-state and the cyclical behavior of the informal sector (i.e. the long-run trends and cycles as the title suggests) by modelling the intersectoral margins for the firm.

Fiess et al. (2006) model a formal (salaried tradable) sector and an informal (selfemployment non-tradable) sector in a Rogoff-Obstfeld small economy with the aim to capture the sector origin of the shock through variation in the real exchange rate. What are the drivers of large wage movements? A part from the origin of the shock, wage rigidities can explain the cyclical behavior of the informal sector. As discussed in section 2, the informal sector does not seem to simply behave in a way to absorb shocks during negative shocks and recessions. The informal sector in the paper is characterized, a part from self-employment, by credit constraints and a different technology. All workers are homogeneous when salaried workers, while they produce in proportion to their entrepreneurial capability when informal self-employed. The model includes an occupational choice where the marginal individual is indifferent between salaried work and self-employment. Finally, the authors introduce potential wage rigidities in the formal salaried sector. The commovement of relative sector sizes are analyzed and the authors show how there is evidence 
in favor of, both, the segmented and the voluntary view of the informal sector depending on the origin of the shock and the presence of wage rigidities in the formal labour market.

\subsection{Endogenous growth and informality}

The growth literature has made much progress in identifying the determinants of economic growth since mid 1980s and recently started explaining why growth rates vary across countries. As discussed in a special lecture by Hsieh (2009), potential determinants of such variation include misallocation of inputs across firms and industries as well as informality and, nevertheless, the growth literature has paid little attention to the relationship between growth and informality.

A few endogenous growth models with the presence of the informal sector are reviewed here, such as Loayza (1997), Sarte (1997) and Dasgupta (2005). As in the present survey, Loayza (1997) discusses the rationality of being informal in the light of the costs and benefits of legality of businesses and recognizes the importance of government-provided goods and services as they are part of costs of informality and congested by informal production. Loayza (1997) develops an AK-type endogenous model that exhibits constant returns to capital Rebelo (1991) in which the assumption of Barro and Sala-i Martin (1992) is incorporated that the relative amount of public services to aggregate production available to individual agents determines the capital rate of returns. In this framework, agents in the formal sector pay a proportional fraction of income as taxes while agents in the informal sector pay a proportional fraction of income as penalties for being illegal and thus they have a limited access to available public services. Agents are assumed to freely

move across sectors. Public services are assumed to be financed by taxes on production of the formal sector and to be positively affected by the quality of government institutions. To reflect congestible public services, the relative size of the informal sector is devised to reduce capital productive for all agents in the economy. Within this framework, the equilibrium is to be set where formal and informal rates of returns equate. The model predicts that the relative size of the informal sector has a negative impact on economic growth particularly in economies with high tax burden and week enforcement systems that in general increase the size of the informal sector.

Another study that follows similar arguments in an endogenous growth framework is 
Sarte (1997) that examines the effect of rent-seeking behaviors of bureaucrats on economic growth. Sarte (1997) develops a growth model based on Romer (1990) by incorporating both the presence of congestion in enforcing property rights and the bureaucratic rentseeking behaviors in regulation and taxation that limit entry into the formal sector. From this model, it was found that such rent-seeking bureaucracies force marginal firms to move into the informal sector even if they would face high costs of informality, leading to lower growth of the entire economy. In the case of the low cost of informality, on the other hand, entry conditions do not bind and a large number of firms would operate in the informal sector. As pointed out by Nikopour et al. (2008), however, it is not surprising to have a negative association between informality and economic growth because two growth models reviewed above have been built on the strong assumption that the production technology is basically determined by congestible tax-financed public services.

In contrast, Dasgupta (2005) recently develops an endogenous growth model with informal credit markets and shows a positive effect of informality on growth. Unlike previous studies, Dasgupta (2005) employs a dynamic general equilibrium framework in order to resolve the endogeneity issue between financial development and growth. Similar to those assumptions on financial markets discussed in the previous section, it is assumed that households can borrow formally and informally and firms are heterogeneous with different degree of risk on which banks have asymmetric information. Households are also assumed to invest in human capital with financial costs rather than time costs. Within the framework with the credit rationing regime that developing countries mostly take, it is shown that informal financial markets separate the high risk firms from the low risk ones and thus reduce the cost of credit rationing and increase the growth rates. Even higher growth rates are expected when economies take the self revelation regime in which banks formulate an incentive mechanism based on each firm's self-selected demand and set various lending rates.

\subsection{New Keynesian models with informal labour markets}

A series of papers incorporate the search and matching approach into DSGE models to explain the cyclical behavior of employment, job creation and job destruction in response 
to a monetary policy shock as well as the impact on the inflation rate. ${ }^{27}$ In general there is a rapidly growing literature on search matching labour market in New Keynesian DSGE models in addition to Ravenna and Walsh (2007). Christiano et al. (2007) and Thomas (2008) introduce labour market frictions in New Keynesian models allowing the study of, both, the intensive and the extensive margin of labour usage during the business cycle. Blanchard and Gali (2007) adopt a simpler hiring cost approach in a New Keynesian framework.

Castillo and Montoro (2008) develop Blanchard and Gali (2007) by modelling a dual labour market economy with formal and informal labour contracts within a New Keynesian model with labour market frictions. This is the first paper that analyzes together the creation of informal jobs and the interaction between the informal sector and monetary policy. Informality is a result of hiring costs, which are a function of the ratio of vacancies to unemployment (labour market tightness). In equilibrium, firms in the wholesale sectors balance the higher productivity of a formal production process with the lower hiring costs of the informal process. Marginal costs will then become a function also of the proportion of informal jobs in the economy. The interesting results of this theoretical framework is that during period of high aggregate demand the informal sector expands due to lower hiring costs associated with this technology. This creates a link between informality, the dynamics of inflation and the transmission mechanism of monetary policy. In particular, the authors show that "informal workers act as a buffer stock of labour that allows firms to expand output without putting pressure on wages".

Batini et al. (2009) adopt a similar approach by modelling the presence of an 'unobservable' classical labour market together with a wage norm to summarize frictions in the formal sector. This allows a general equilibrium analysis which is more in the Harris and Todaro tradition (Harris and Todaro, 1970) and the study of the link between inflation and unemployment. The authors conclude that the benefits from reducing the informal sector - i.e. tax smoothing and net benefits from stabilization with tax smoothing - outweigh the cost in terms of less wage flexibility.

\footnotetext{
${ }^{27}$ See Yasgiv (2007) for a survey on the developments of search-matching models and (Ravenna and Walsh (2007)) for a recent application of search frictions in New Keynesiam models.
} 


\section{Conclusions}

Since the initial studies on informality (ILO, 1972) and the influential work of De Soto (1989), empirical and theoretical findings on the informal economy have been extensive and often contrasting. Furthermore, the concept of informality has changed over time. Chen (2007) describes the move from the 'old' view of an informal sector to a more comprehensive concept of the informal economy (i.e. from the characteristics of the firm to the characteristics of the employment relationship). ${ }^{28}$ Open questions on the definition, methods of estimation, causes and effects of the informal economy point to the need for more work in the area.

We have reviewed two main approaches. A strand of the informality literature focuses on the theoretical issues of informality in the credit market. Another strand of theoretical research investigates informality in the labour market. The two modelling approaches address many of the stylized fact describes in section 2.4 (SF3, SF4, SF5, SF6, SF7 and SF8 for the informal employment and SF15, SF18, SF19, SF20, SF21 and SF22 for the informal credit markets), while others require further development (SF1, SF2, SF13, and SF14 for the informal employment and SF 16 and SF17 for the informal credit markets). Clearly, the two views share many theoretical and policy issues. In general, we are left with few key questions. How effective are government policies in countries with a large informal (and often) unobservable labour/credit markets? What are the links between informality and (endogenous) growth? Can informality be good in some respects? What is the link between informality and gender inequality? Our assessment of the literature is that most of the existing models, though relevant, share a partial equilibrium approach to informality. A closer scrutiny of the phenomenon able to capture various aspects of informality (i.e. multi-informality in the product, labour and credit markets) requires a dynamic general equilibrium approach in which households' and producers' choices over time are explicitly taken into account.

\footnotetext{
${ }^{28}$ See ILO (1972), ILO (2002) and Table 2 for details.
} 


\section{References}

Agenor, P. and Montiel, P. (1996). Development Macroeconomics. Princeton University Press, New Jersey.

Albrecht, J., Navarro, L., and Vroman, S. (2008). The Effects of Labor Market Reforms in an Econoy with an Informal Sector. Mimeo.

Antunes, A. and Cavalcanti, T. (2007). Start up costs, limited enforcement, and the hidden economy. European Economic Review, 51, 203-224.

Arnott, R. and Stiglitz, J. E. (1991). Moral Hazard and Nonmarket Institutions: Dysfunctional Crowding Out or Peer Monitoring? The American Economic Review, 81, 179-190.

Aryeetey, E., Hettige, H., Nissanke, M., and Steel, W. (1997). Financial Market Fragmentation and Reforms in Ghana, Malawi, Nigeria, and Tanzania. World Bank Economic Review, 11, 195-218.

Ayyagari, M., Kunt, D., and Maksimovic, V. (2008). Formal versus Informal Finance: Evidence from China. Policy Research Working Paper 4465, World Bank.

Badaoui, E., Strobl, E., and F., W. (2006). An Equilibrium Search Model of the Informal Sector. Mimeo.

Banerjee, A. V. (2003). Contracting Constraints, Credit Markets, and Economic Development. In Advances in Economics and Econometrics: Theory and Applications, Eighth World Congress, Volume III, ed. Mathias Dewatripont, Lars Peter Hansen and Stephen Turnovsky. Cambridge University Press pp. 146.

Banerjee, A. V. and Duflo, E. (2007). The Economic Lives of the Poor. Journal of Economic Perspectives, 21(1), 141-167.

Banerjee, A. V., Besley, T., and Guinnane, T. W. (1994). The Neighbor's Keeper: The Design of a Credit Cooperative with Theory and a Test. Quarterly Journal of Economics, 109, 491-515. 
Barro, R. and Sala-i Martin, X. (1992). Public Finance in Models of Economic Growth. The Review of Economic Studies, 59, 645-661.

Barth, J. R., Caprio Jr, G., and Levine, R. (2004). Bank Regulation and Supervision: What Works Best? Journal of Financial Intermediation, 13(2), 205-248.

Batini, N., Levine, P., and Lotti, E. (2009). Monetary Policy and the Informal Economy. mimeo.

Beck, T., Kunt, A. D., and Maksimovic, V. (2004). Bank Competition and Access to Finance: International Evidence. Journal of Money, Credit, and Banking, 36(3), 627648.

Becsi, Z., Li, V., and P., W. (2005). Heterogeneous borrowers, liquidity, and the search for credit. Journal of Economic Dynamics and Control, 29(8), 1331-1360.

Bell, C. K. (1990). Interactions between Institutional and Informal Credit Agencies in Rural India. The World Bank Economic Review, 4(3), 297-327.

Besley, T. (1994). How Do Market Failures Justify Interventions in Rural Credit Markets? The World Bank Research Observer, 9(1), 27-47.

Blanchard, O. and Gali, J. (2007). A New Keynesian Model with Unemployment. Centre for Financial Studies WP No, 2007/08.

Boeri, T. and Garibaldi, P. (2005). Shadow Sorting. in Pissarides C. and J. Frenkel NBER Macroeconomics Annual MIT Press.

Bosch, M. (2006). Job Creation and Job Destruction in the Presence of Informal Labour Markets. Mimeo, London School of Economics.

Bosch, M. (2007). On the Three Margins of Informality. Mimeo, London School of Economics.

Bosch, M. and Maloney, W. (2006). Gross Worker Flows in thePresence of Informal Labor Markets. The Mexican Experience 1987-2002. Mimeo.

Bosch, M. and Maloney, W. (2007). The Determinants of Rising Informality in Brasil: Evidence from Gross Workers Flows. Mimeo. 
Bose, P. (1998). Formal-Informal Sector Interaction in Rural Credit Markets. Journal of Development Economics, 56, 256-280.

Brueckner, J. and Zenou, Y. (1999a). Harris-Todaro models with a land market. Regional Science and Urbal Economics, 29, 317-339.

Brueckner, J. K. and Zenou, Y. (1999b). Harris-Todaro models with a land market. Regional Science and Urbal Economics, 29, 317-339.

Burdett, K. and Mortensen, D. (1998). Wage differentials, employer size and unemployment. International Economic Review, 39, 25-74.

Castillo, P. and Montoro, C. (2008). Monetary Policy in the Presence of Informal Labour Markets. Mimeo, Banco Central de Reserva del Peru.

Cavalcanti, T. and Villamil, A. (2003). Optimal Inflation Tax and Structural Reform. Macroeconomic Dynamics, 7, 333-362.

Chaudari, K., Schneider, F., and Chattopadhyay, S. (2006). The Size and Development of the Shadow Economy: An Empirical Investigation from States of India. Journal of Development Economics, 80, 428-443.

Chen, M. A. (2007). Rethinking the Informal Economy: Linkages with the Formal Economy and the Formal Regulatory Environment. DESA WP N.46.

Chen, X. and Degryse, H. (2008). The Impact of Banks and Non-Bank Financial Institutions on Local Economic Growth in China. mimeo, Tilburg University.

Christiano, L. J., Trabandt, M., and Walentin, K. (2007). Introducing Financial Frictions into a Small Economy Model. Sveriges Riksbank Working Paper No. 214.

Conesa, J. C., Diaz-Moreno, C., and Galdon-Sanchez, J. E. (2002). Explaining CrossCountry Differences in Partication Rates and Aggregate Fluctuations. Journal of Economic Dynamics and Control, 26, 333-345.

Conning, J. (2001). Mixing and Matching Loans: Credit Rationing and Spillover in a Rural Credit Market in Chile. mimeo, Williams Colleg. 
Cull, R. and Xu, L. C. (2005). Institutions, Ownership, and Finance: The Determinants of Profit Reinvestment Among Chinese Firms. Journal of Financial Economics, 77(1), $117-146$.

Das-Gupta, A., Nayar, C. P. S., and Associates (1989). Urban Informal Credit Markets in India. New Delhi: National Institute of Public Finance and Policy.

Dasgupta, B. (2005). Endogenous Growth in the Presence of Informal Credit Markets: A Comparative Analysis Between Credit Rationing and Self-Revelation Regimes. Economics Working Papers, University of Connecticut.

de Paula, A. and Scheinkman, J. (2007). The Informal Sector. PIER Working Paper $07-35$.

De Soto, H. (1989). The Other Path. Harper and Row, New York.

Dell'Anno, R. (2003). Estimating the shadow economy in Italy: A structural equation approach. University of Aarhus WP.

Dell'Ariccia, G. and Garibaldi, G. (2000). Gross Credit Flows. CEPR Working Paper, 2569.

Fields, G. (1975). Rural-urban migration, urban unemployment and underemployment, and job search activity in LDCs. Journal of Development Economics, 2, 165-182.

Fields, G. (2005). A Guide to Multisector Labor Market Models. Social Protection Discussion Paper Series No.0505. The World Bank.

Fiess, N., Fugazza, M., and Maloney, W. (2006). Informal Labor Markets and Macroeconomic Fluctuations. mimeo.

Floro, M. S. and Ray, D. (1997). Vertical Links Between Formal and Informal Financial Institutions. Review of Development Economics, 1(1), 34-56.

Frankel, J. and Pissarides, C. (2006). Comments on T. Boeri and P. Garibaldi Shadow Sorting in International Seminar on Macroeconomics. MIT Press.

Fry, M. (1978). Money and Capital or Financial Development in Economic Development. Journal of Money Banking and Credit, 10, 464-475. 
Fugazza, M. and Jacques, J.-F. (2003). Labor market Institutions, taxation and the underground economy. Journal of Public Economics, 88, 395-418.

Garibaldi, P. and Wasmer, E. (2001). Labour Markets Flows and Equilibrium Search Unemployment. IZA Discussion Paper, No. 406.

Ghatak, S. (2007). Monetary Economics in Developing Countries. Palgrave, 3rd edition.

Ghatak, S. and Chandio, R. (2009). Financial Repression and economic growth in Pakistan: A co-integration analysis. Journal of Finacial Decision Making, 5, 15-23.

Ghate, P., Das-Gupta, A., Lamberte, M., Poapongsakorn, N., Prabowo, D., Rahman, A., and Srinivasan, T. (1992). Informal Finance: Some Findings From Asia. Oxford University Press, Manila, Philippines.

Ghosh, P., Mookherjee, D., and Ray, D. (1999). Credit Rationing in Developing Countries: An overview of the theory. Published in A Reader of Development Economics,2000 London.

Gibson, B. and Kelley, B. (1994). A Classical Theory of the Informal Sector. The Manchester School LXII No.1.

Gine, X. (2007). Access to Capital in Rural Thailand: An Estimated Model of Formal vs. Informal Credit. Research Working Paper WPS 3502 World Bank.

Harris, J. and Todaro, M. (1970). Migration, Unemployment, and Development: A two sector Analysis. American Economic Review, 40, 126-142.

Henley, A., Arabsheibani, G., and Carneiro, F. (2006). On defining and measuring the informal sector. IZA Discussion Paper, 2473.

Hoff, K. and Stiglitz, J. E. (1990). Introduction: Imperfect Information and Rural Credit Markets - Puzzles and Policy Perspectives. The World Bank Economic Review, 4(3), $235-250$.

Hoff, K. and Stiglitz, J. E. (1997). Moneylenders and Bankers: Price-Increasing Subsidies in A Monopolistically Competitive Market. Journal of Development Economics, 52, 429-462. 
Hsieh, C. T. (2009). What Have We Learn about Growth? Special Lecture, The 2009 Annual Conference of the Royal Economic Society.

Ihrig, J. and Moe, K. (2004). Lurking in the Shadows: the Informal Sector and Government Policies. Journal of Development Economics, 73, 541-557.

ILO (1972). Employment, Incomes and equality: a strategy for increasing productive employment in Kenya. Mimeo, Geneva.

ILO (2002). Women and Men in the Informal Economy: A Statistical Picture. Mimeo, Geneva.

Irfan, M., Arif, G., Ali, S. M., and Nazli, H. (1999). The Structure of Informal Credit Market in Pakistan. Research Report No. 168 Pakistan Institute of Development Economics.

Kochar, A. (1997). An Empirical Investigation of Rationing Constraints in Rural Credit Markets in India. Journal of Development Economics, 53, 339-371.

Kolm, A. and Larsen, B. (2003). Does Tax Evasion affect unemployment and educational choice? WP 12 Copenhagen Business School.

Lall, S., Selod, H., and Shalizi, Z. (2006). Rural-Urban Migration in Developing Countries: A Survey of Theoretical Predictions and Empirical Findings. WP 3915 World Bank.

Lewis, A. (1954). Economic Development with Unlimited Supplies of Labour. Manchester School, 22, 139-191.

Loayza, N. V. (1997). The Economics of the Informal Sector: A Simple Model and Some Empirical Evidence from Latin America. Policy Research Working Paper No. 1727, The World Bank.

Loayza, V. (1996). The economics of the informal sector: a simple model and some empirical evidence from Latin America. Carnegie-Rochester Conference Series on Public Policy, 45.

Loyaza, N. and Rigolini, J. (2006). Informality Trends and Cycles. mimeo. 
Lucas, R. J. (1978). On the Size Distribution of Business Firms. Bell Journal of Economics, $\mathbf{9}(2), 508-523$.

Madestam, A. (2009). Informal Finance: A Theory of Moneylenders. Mimeo, Department of Economics, Bocconi University.

Maloney, W. (1999). Does Informality Implies Segmentation in Urban Labour Markets? Evidence from Sectoral Transition in Mexico. World Bank Economic Review, 13.

Maloney, W. (2004). Informality Revisited. World Development, 32(7), 1159-1178.

Marjit, S. and Kar, S. (2008). A Contemporary Perspective on the Informal Labor Market - Theory, Policy and the Indian Experience. Mimeo, Centre for Studies in Social Science, Calcutta.

Martin, G. (2000). Employment and Unemployment in Mexico in the 1990s. Monthly Labor Review, 123, 3-18.

Mastalioglu, W. and Rigolini, J. (2006). Informality Traps. mimeo.

McKenna, C. (1987). Labour Market Participation in Matching Equilibrium. Economica, 54, 325-333.

McKinnon, R. (1973). Money and Capital in Economic Development. Brookings, Washington D.C.

NCEUS (2008). Report on definitional and statistical issues related to the informal economy. National Commission for Enterprises in the Un-organized Sector, New Delhi.

Nikopour, H., Shah, H. M., and Schneider, F. (2008). The shadow economy Kuznets's curve panel data analysis. Department of Economics, University Putra Malaysia.

Ortega, J. (2000). Pareto-improving immigration in an economy with equilibrium unemployment. Economic Journal, 110, 92-112.

Perry, G., Maloney, W., Arias, O., Fajnzylber, P., Mason, A., and Saavedra-Chanduvi (2007). Informality: Exit and Esclusion. World Bank Report. 
Portes, A., Castells, M., and Benton, L. (1989). The Informal Economy: Studies in Advanced and Less Developed Countries. John Hopkins Press, Baltimore.

Rauch, J. (1991). Modelling the Informal Sector Formally. Journal of Development Economics, 35, 33-47.

Ravenna, F. and Walsh, C. E. (2007). Vacancies, Unemployment and the Phillips Curve. Mimeo.

Rebelo, S. (1991). Long-Run Policy Analysis and Long-Run Growth. Journal of Political Economy, 99, 500-521.

Rei, D. and Battacharya, M. (2008). The Impact of Institutions and Policy on Informal Economy in Developing Countries: An Econometric Exploration. ILO Working Paper, No. 84 .

Romer, P. (1990). Endogenous Technical Change. Journal of Political Economy, 98, S71-102.

Sarte, P. D. (1997). Informality and Rent-Seeking Bureaucracies in a Model of Long Run Growth. Research Department, Federal Reserve Bank of Richmond, Working Paper 99-7.

Satchi, M. and Temple, J. (2009). Labor Markets and Productivity in Developing Countries. Review of Economic Dynamics, 26, 333-345.

Sato, Y. (2004). Migration, frictional unemployment, and welfare improving labour policies. Journal of Regional Science, 44, 773-793.

Schneider, F. (2005). Shadow Economies around the World: What Do We Really Know? European Journal of Political Economy, 21(3), 598-642.

Schneider, F. and Enste, D. (2000). Shadow Economies: Size, Causes and Consequences. Journal of Economic Literature, 38, 77-114.

Shaw, E. (1973). Financial Development in Economic Development. Oxford University Press, Oxford. 
Siamwalla, A., Pinthong, C., Poapongsakorn, N., Satsanguan, P., Nettayarak, P., Mingmaneenakin, W., and Tubpun, Y. (1990). The Thai Rural Credit System: Public Subsidies, Private Information, and Segmented Markets. World Bank Economic Review, 4(3), 271-295.

Sinha, A. (2005). Impact of Reforms on the Informal Sector: Poverty Analysis through a CGE Approach. mimeo National Council of Applied Economic Research.

Sinha, A. and Adam, C. (2000). Trade Policy Reform and the Informal Sector in India. paper presented at the 13th International Conference on Input-Output Techniques at Macerata.

Solomon, O. (2008). Accounting for the Size of the Informal Sector in Nigeria. mimeo London Metropolitan University.

Stiglitz, J. E. (1990). Peer Monitoring in Credit Markets. World Bank Economic Review, 4, 351-366.

Straub, S. (2005). Informal Sector: The Credit Market Channel. Journal of Development Economics, 78, 299-321.

Taylor, L. (1983). Structuralist Macroeconomics: Applicable models for the third world. Basic Books, New York.

Thomas, C. (2008). Search and Matching Frictions and Optimal Policy. Journal of Monetary Econsomic, pages 936-956.

Thornton, J. and Poudyal, S. (1990). Money and Capital in Economic Development: A Test of the McKinnon Hypothesis for Nepal. Journal of Money Credit and Banking, 22, 395-399.

Todaro, M. P. (1969). A Model of Labor Migration and Urban Unemployment in Less. Developed Countries. American Economic Review, 59, 138-148.

van Wijnbergen, S. (1982). Stagflationary effects of monetary stabilization policies: A quantitative analysis of South Korea. Journal of Development Economics, 10(2), 133164. 
Wahba, J. and Zenou, Y. (2005). Density, social networks and job search methods: theory and application to Egypt. Journal of Development Economics, 78, 443-473.

Wasmer, E. and Weil, P. (2004). The Macroeconomics of Labor and Credit Imperfections. American Economic Review, 94(4), 944-963.

Yasgiv, E. (2007). Labor Search and Matching in Macroeconomics. European Economic Review, pages 1859-1895.

Yunus, M. and Weber, K. (2007). Creating a world without poverty: Social Business and the Future of Capitalism. BBs Public Affairs, New York.

Zenou, Y. (2008). Job Search and Mobility in Developing Countries: Theory and Policy Implications. Journal of Development Economics, 86, 336-355. 
Table 1: Informality

\begin{tabular}{cccccc}
\hline \hline & View & Dualism & Markets & Processes/Goods/Services & Linkages \\
\hline \multirow{2}{*}{ Productive } & scale & product & legal & Dualist & \\
legalistic & wage & labour & illegal & structuralist & \\
& evasion & credit & & legalistic & \\
\hline \hline
\end{tabular}

Table 2: Views for the informal economy from Table 1 in Chen (2007)

\begin{tabular}{cc}
\hline \hline The old view: ILO $\mathbf{1 9 7 2}$ & The new view: ILO 2002 \\
\hline traditional economy that will disappear & here to stay and expand \\
only marginally productive & contributes significantly to GDP \\
separate from formal economy & linked with formal economy \\
represents a reserve pool of surplus labour & inf. due to less formal jobs or informalization \\
street traders and small-scale producers & wide range of informal occupations \\
entrepreneurs who avoid taxes/regulations & wage workers, entrepreneurs and self-empl. \\
\hline \hline
\end{tabular}


Table 3: Informal economy as a percentage of GDP

\begin{tabular}{|c|c|c|c|}
\hline & \multicolumn{3}{|c|}{ Unweighted Average* } \\
\hline & 1989-1991 & $1994 / 1995$ & 1999-2000 \\
\hline 24 African countries & 33.9 & 37.4 & 41.2 \\
\hline 25 Asian countries & 20.9 & 23.4 & 26.3 \\
\hline 17 countries Cent. and South America & 34.2 & 37.7 & 41.5 \\
\hline 23 Transitional countries & 31.5 & 34.6 & 37.9 \\
\hline 21 OECD countries & 13.2 & 15.7 & 16.7 \\
\hline
\end{tabular}

Notes: *Unweighted average from Schneider (2005). 
Table 4: Search matching models: classification

\begin{tabular}{ccccc}
\hline \hline Papers & Heterogeneity & Informality choice & Informal workers status \\
\hline Albrecht et al. 2005 & heterogeneous formal workers & endogenous worker's choice & informal self-employed \\
Boeri-Garibaldi 2005 & heterogeneous skills & end. worker's and firm's choice & employed in LM* with frictions \\
Bosch 2006 & homogeneous but SJM** & intrafirm margin & employed in LM with frictions \\
Bosch 2007 & heterogeneous but SJM** & intrafirm margin+occup. choice & informal self-employed \\
Fugazza and Jacques 2003 & heterogeneous informal workers & endogenous firm and worker choice & employed in LM* with frictions \\
Satchi and Temple 2008 & homogeneous & endogenous worker's choice & unemployed in LM* with frictions \\
Zenou 2008 & homogeneous, different sector TFPs & endogenous worker's choice & employed in competitive LM* &
\end{tabular}

Notes: ${ }^{*} \mathrm{LM}=$ Labor markets ${ }^{* *} \mathrm{SJM}=$ stochastic job matching 
Table 5: Towards a general equilibrium approach to informality

\begin{tabular}{|c|c|c|c|c|c|}
\hline \multirow[t]{2}{*}{ Papers } & \multirow[t]{2}{*}{ Informality } & \multirow[t]{2}{*}{ Partial } & \multirow[t]{2}{*}{ DGE } & \multicolumn{2}{|c|}{ DSGE } \\
\hline & & & & RBC & NK \\
\hline Boeri and Garibaldi (2005) & Labor & $\mathrm{X}$ & & & \\
\hline Bosch $(2006,2007)$ & Labor & $\mathrm{x}$ & & & \\
\hline Frankel and Pissarides (2006) & Labor & $\mathrm{X}$ & & & \\
\hline Albrecht et al. (2008) & Labor & $\mathrm{X}$ & & & \\
\hline Zenou (2008) & Labor & $\mathrm{X}$ & & & \\
\hline Satchi and Temple (2009) & Labor & $\mathrm{X}$ & & & \\
\hline Fiess et al. (2006) & Labor & & $\mathrm{X}$ & & \\
\hline Conesa et al. (2002) & Labor & & & $\mathrm{X}$ & \\
\hline Fugazza and Jacques (2003) & Labor & & & $\mathrm{X}$ & \\
\hline Ihrig and Moe (2004) & Product & & & $\mathrm{x}$ & \\
\hline Castillo and Montoro (2008) & Labor & & & & $\mathrm{X}$ \\
\hline Marjit and Kar (2008) & Labor & & & & $\mathrm{x}$ \\
\hline Solomon (2008) & Labor & & & & $\mathrm{x}$ \\
\hline Batini et al. (2009) & Labor & & & & $\mathrm{X}$ \\
\hline Wasmer and Weil (2004) & Labor+Credit & $\mathrm{x}$ & & & \\
\hline de Paula and Scheinkman (2007) & Labor+Credit & $\mathrm{X}$ & & & \\
\hline Cavalcanti and Villamil (2003) & Labor+Credit & & $\mathrm{x}$ & & \\
\hline Bell (1990) & Credit & $\mathrm{X}$ & & & \\
\hline Arnott and Stiglitz (1991) & Credit & $\mathrm{X}$ & & & \\
\hline Banerjee et al. (1994) & Credit & $\mathrm{x}$ & & & \\
\hline Floro and Ray (1997) & Credit & $\mathrm{X}$ & & & \\
\hline Hoff and Stiglitz (1997) & Credit & $\mathrm{x}$ & & & \\
\hline Kochar (1997) & Credit & $\mathrm{X}$ & & & \\
\hline Bose (1998) & Credit & $\mathrm{X}$ & & & \\
\hline Dell'Ariccia and Garibaldi (2000) & Credit & $\mathrm{X}$ & & & \\
\hline Antunes and Cavalcanti (2007) & Credit & $\mathrm{x}$ & & & \\
\hline Madestam (2009) & Credit & $\mathrm{X}$ & & & \\
\hline Dasgupta (2005) & Credit & & $\mathrm{X}$ & & \\
\hline Loayza (1997) & Product & & $\mathrm{X}$ & & \\
\hline Sarte (1997) & Product & & $\mathrm{X}$ & & \\
\hline
\end{tabular}

